\title{
Thyroid spindle epithelial tumor with thymus-like differentiation (SETTLE): case report and review
}

\author{
Tumor epitelial de células fusiformes com diferenciação \\ thymus-like da tireoide (SETTLE): relato de caso e revisão da literatura
}

Luiz Antônio Magnata Filho',2, Maria Alice Neves Bordallo',

Cencita H. C. N. Pessoa', Rossana Corbo', Daniel Alves Bulzico',

Fernando Luiz Dias ${ }^{3}$, Avelino L. Machado4, Andréia B. Soares², Sima Ferman ${ }^{4}$

\section{SUMMARY}

Spindle epithelial tumor with thymus-like element (SETTLE) is a rare malignant neoplasm of the thyroid, occurring predominantly in children, adolescents, and young adults. SETTLE usually presents itself as a thyroid mass, without metastases at diagnosis. It is believed to derive from branchial pouch or thymic remnant tissue showing primitive thymic differentiation. This article reports the clinical, cytological, histological and immunohistochemical features of a SETTLE in a 3-year-old girl. Microscopic exam revealed a nodular, highly cellular neoplasm displayed in the classic biphasic pattern, with mixture of prominent spindle cell component and a minor glandular component lined by mucinous or respiratory-type epithelium. The immunohistochemical study showed strong and diffuse positivity for pan-CK, vimentin and smooth muscle actin. The present case is the first SETTLE case reported in Brazil. To date, the patient described remains without evidence of recurrence or metastasis 5 years after surgery. Arq Bras Endocrinol Metab. 2010;54(7):657-62

\section{SUMÁRIO}

O tumor epitelial de células fusiformes com elemento thymus-like é uma rara neoplasia maligna da tireoide, ocorrendo predominantemente em crianças, adolescentes e adultos jovens. Habitualmente, esse tumor se apresenta como massa tireoideana, sem metástases ao diagnóstico. Acredita-se derivar de arco branquial ou tecido remanescente tímico, apresentando diferenciação tímica primitiva. Este artigo descreve os aspectos clínicos, citológicos, histológicos e imuno-histoquímicos de um caso de SETTLE diagnosticado em uma menina de 3 anos de idade. 0 aspecto microscópico encontrado no tumor foi de uma lesão nodular, hipercelular, disposta em aspecto bifásico clássico, com componente de células fusiformes, e de tecido glandular acompanhado por epitélio mucinoso e respiratório. $O$ estudo imuno-histoquímico foi positivo para pan-CK, vimentina e actina de músculo liso. Esse caso é o primeiro relato de SETTLE no Brasil. A paciente descrita permanece sem evidência de doença em atividade cinco anos após o tratamento cirúrgico. Arq Bras Endocrinol Metab. 2010;54(7):657-62

\section{INTRODUCTION}

$\mathrm{T}$ he spindle epithelial tumor with thymus-like element (SETTLE) is a very rare neoplasm related to the thyroid of young individuals. According to the US National Center for Biotechnology Research (PubMed database), the term SETTLE has been reported only 26 times in the English literature until July of 2010. In 1991, Chan and Rosai (1) unified the concept of SETTLE when they described 8 neoplasms situated in the neck and thyroid
${ }^{1}$ Department of Pediatric Endocrinology, Instituto Nacional de Câncer (Inca), Rio de Janeiro, RJ, Brazil 2 Division of Pathology, Inca, Rio de Janeiro, RJ, Brazil ${ }^{3}$ Department of Head and Neck Surgery, Inca, Rio de Janeiro, RJ, Brazil ${ }^{4}$ Department of Pediatric Oncology, Inca, Rio de Janeiro, RJ, Brazil
Correspondence to: Maria Alice Neves Bordallo Praia de Botafogo 132, ap. 501 22250-040 - Rio de Janeiro, RJ, Brazil

malicebordallo@terra.com.br

Received on Apr/13/2010 Accepted on Aug/21/2010 of children and young adults, previously diagnosed as malignant teratoma of the thyroid, thyroid spindle cell tumor with mucous cysts or thyroid thymoma. SETTLE is a distinct low-grade neoplasm, believed to be derived from branchial pouch or thymic remnants, with only 1 case report showing association with epithelium-lined cysts of possible branchial pouch derivation (2). It belongs to a group of cervical lesions that includes ectopic cervical thymoma, ectopic hamartomatous thymoma and 
carcinoma with thymus-like element (CASTLE) (3). This tumor is composed predominantly of spindle and epithelioid cells with glandular or ductular structures lined by a mucinous or respiratory epithelium (4). In spite of indolent growth, SETTLE may give metastases many years after the diagnosis. Therefore, a long-term follow-up is required. We present one case, the first report from Brazil, of a patient who has benign clinical course and tumoral features suggestive of a myoepithelial differentiation. The clinicopathologic features of the case reports in the literature are also reviewed.

\section{CASE REPORT}

A 3.5 year-old girl was referred to the Brazilian National Cancer Institute with a mass in the right lobe of the thyroid. Laboratory exams showed normal free-T3 free; free-T4 and TSH levels. Neck ultrasonography revealed a $2.3 \times 1.8 \times 1.4 \mathrm{~cm}$ heterogeneous solid mass which occupied the entire right lobe of the thyroid. There was also bilateral enlargement of lymph nodes at the second cervical level. The thyroid scintigraphy showed decrease of radioactive iodine. Chest tomography and abdominal ultrasonography were normal.

The fine needle aspiration (FNA) cytological study performed was inconclusive. Therefore, resection of the mass was suggested and partial thyroidectomy performed 2 months later. The final diagnosis was SETTLE.

Despite no other therapy having been performed, at the present moment the child is alive without evidence of recurrence or metastasis 5 years after the initial treatment.

\section{MATERIAL AND METHODS}

The FNA material was received in physiological solution, processed routinely and stained with Papanicolaou. The surgical specimen was received in $10 \%$ buffered formalin and processed routinely. An immunohistochemical analysis was performed using formalin-fixed, paraffin-embedded tissue sections and the standardized streptavidinbiotin peroxidase complex with $\mathrm{DAB}$ as a chromogen.

\section{RESULTS}

\section{Cytological findings}

The biopsy preparation obtained from the FNA revealed a highly cellular aspirate consisting of cohesive or isolated sheets of spindle cells with clusters of polygonal cells with benign features in a background of cyanophilic material which resembles mucin. The spindle cells showed elongated or oval nuclei, finely dispersed chromatin, inconspicuous nucleoli, distinct nuclear membrane and a high nuclear-cytoplasm ratio. There was minimal cellular pleomorphism and neither necrosis nor mitotic figures was observed.

\section{Pathological findings}

\section{Macroscopic features}

The gross examination of the specimen showed a bosselated, well-circumscribed and firm mass, measuring $2.5 \times 2.0 \times 1.8 \mathrm{~cm}$. The cut surface was solid, grayishbrown, slightly lobular with residual thyroid at the periphery. There were focal cysts and mucoid areas. Necrosis, calcifications and haemorrhage were not observed.

\section{Microscopic features}

Microscopically, the tumor was circumscribed with collagen bands incompletely dividing the tumor in nodules (Figure 1). There was a biphasic pattern composed of a mixture of a predominant component of spindle cells and a minor glandular component with mucinous and respiratory-type epithelium (Figure 2). The mitotic index was low and there were no areas with necrosis or haemorrhage.

The tumor was highly cellular and formed predominantly by reticulated to compact fascicles of spindle cells with a slightly storiform pattern (Figure 3 ). The spindle cells displayed scanty eosinophilic cytoplasm and elongated to plump nuclei. The nuclei were minimally pleomorphic with both pointed and blunt ends, distinct nuclear membranes, delicate chromatin and inconspicuous nucleoli.

The second component of the tumor consisted mainly of glandular and ductular structures lined by mucinous epithelium and ciliated pseudo-stratified epithelium with occasional goblet cells. These structures varied from large cystic spaces to smaller structures and cell clusters, merging imperceptibly with the spindle cells. These cells displayed a columnar to cuboidal nuclei.

Focal areas with squamous epithelium arising abruptly from the spindle cells were observed. There were interstitial mucine pools, intercellular edema and scant lymphocytes.

Normal thyroid tissue was observed in the periphery of the mass, and occasional thyroid follicles were found within the tumor. 


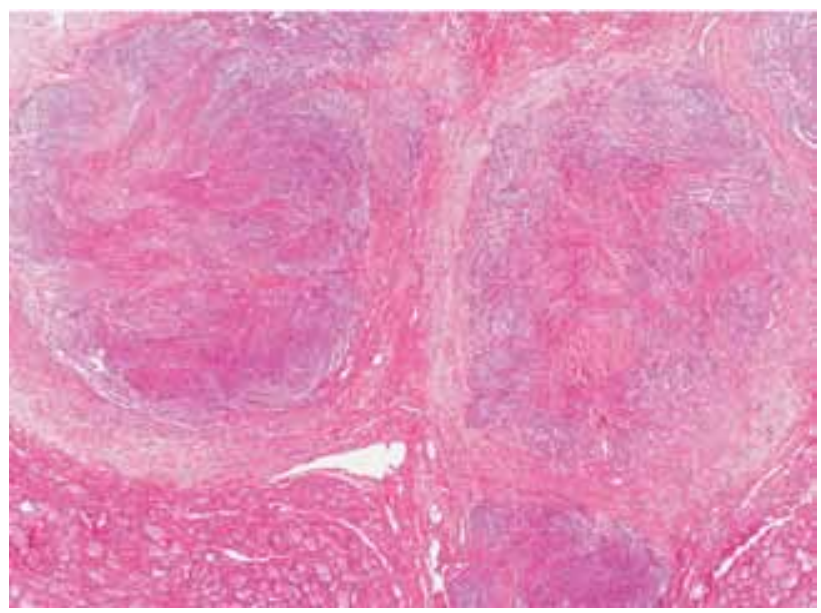

Figure 1. Collagen bands incompletely dividing the tumor in nodules.

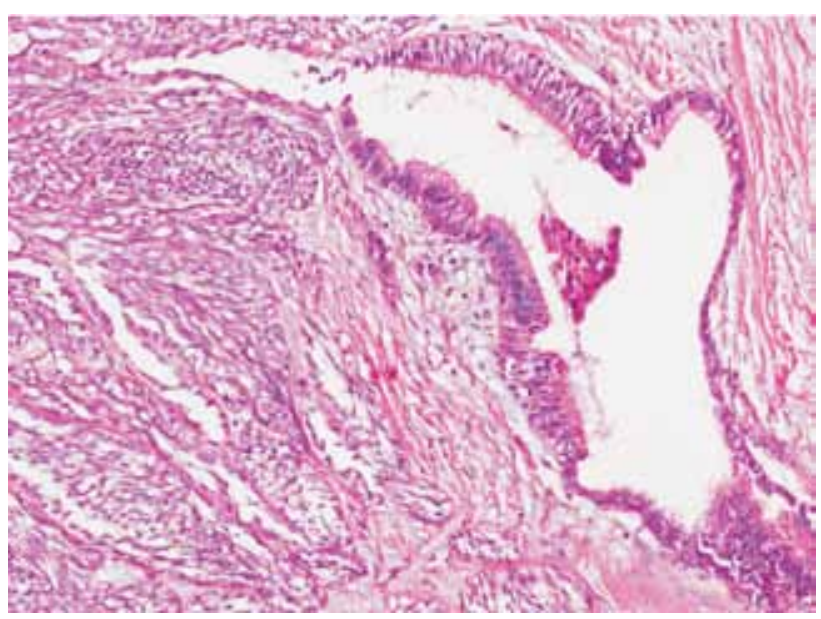

Figure 2. Biphasic pattern composed of a mixture of a predominant component of spindle cells and a glandular component.

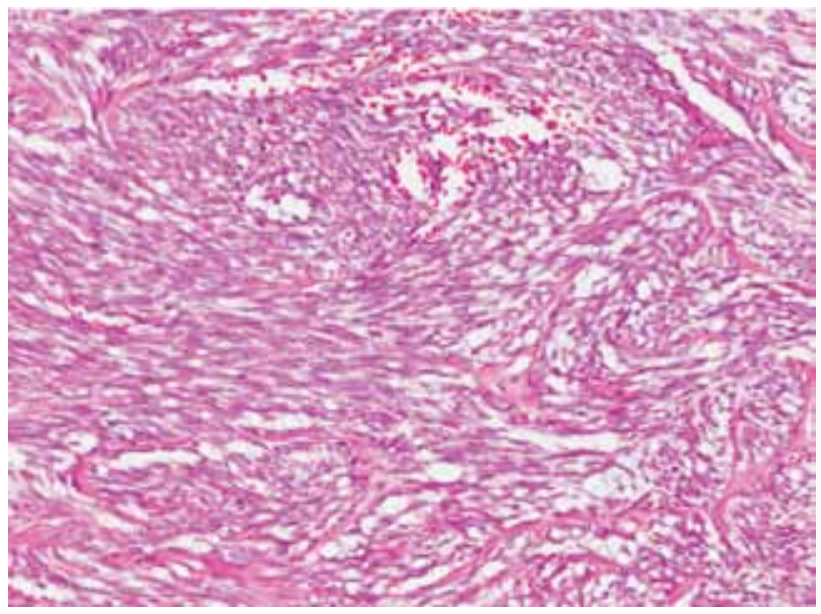

Figure 3. Compact fascicles of spindle cells with a slightly storiform pattern.

\section{Immunohistochemistry}

The immunohistochemical study revealed the tumor strong and with diffuse positivity for $\mathrm{AEl} / 3$, vimentin and smooth muscle actin in both spindle and glandular components. Focal positivity for EMA, mostly in the glandular component, was observed. Desmin, CD5, thyroglobulin, calcitonin, chromogranin, synaptophysin and CEA had negative immunoreactivity.

\section{DISCUSSION}

Up to July, 2010, from the available data in the indexed literature, there were 30 case reports of SETTLE. This rare tumor occurs in young individuals with a mean age of 17.9 years at presentation (ranging from 2 to 59 years), with a male-to-female ratio of 1.1 . In this case, the patient was 3.5 years old at the time of the diagnosis, the first report from Brazil.

The generally initial presentation described is a painless mass, within or around the thyroid. In the literature, there are at least 4 patients who had the thyroid mass noticed for four or more years, which suggest a slow tumoral growth (5-8).

In the majority of the reported cases, disease widespread occurred years after surgical resection of the primary lesion. In spite of the disease progression with metastasis development, low mortality rates are observed, demonstrating the indolent course of the tumor. SETTLE may not produce metastasis until many years after the diagnosis (mean of 11 years) and according to case reports with follow-up information, the overall rate of metastasis is of about $20 \%(2,8-10,12-15)$. Otherwise, when the analysis is made only on patients with more than 5 years of follow-up, the incidence increases to $50 \%(8,12-14)$ with 2 patients developing metastasis more than 20 years after the diagnosis $(13,14)$. Metastatic spread is reported to lung, mediastinum, local lymph nodes and kidney. The principal site of metastasis is the lung, which represents more than $60 \%$ of the metastasis sites $(2,8,10,12,14)$. The gap between diagnosis and detection of metastasis varies from a few months after the primary tumor manifestation to 25 years $(14,15)$.

All descriptions of FNA show a highly cellular aspirate composed mainly of cohesive or isolated sheets of spindle cells. The cells show an elongated to oval nuclei with well defined nuclear membrane, fine chromatin and inconspicuous nucleoli. Nuclear pleomorphism is not found and mitotic figures are rare. Well differentiated polygonal cells and mucin deposits can be found in the background intermingled with the spindle cells $(2,6,16)$. 
Grossly, SETTLE is a well circumscribed tumor, varying in size from 1.8 to $12 \mathrm{~cm}$. It is usually a lobular mass with, sometimes, cysts and mucous focal areas (8).

The external surface of the tumor is frequently bosselated, with firm, gritty, white-gray to brown, slightly lobular and sometimes with cysts, appearance at the cut surface. The residual thyroid is often identified at the periphery of the tumor (17). Haemorrhage, necrosis and infarct areas are generally not observed.

Microscopically the tumor can be circumscribed or infiltrative, with sclerotic bands that incompletely separate the tumor in lobules or nodules. The hallmark feature is a biphasic pattern composed of a predominant component of spindle cells and a minor glandular mucous component, occasionally cystic $(1,3,9)$. The collagen stripes can produce an eosinophilic hyaline mass similar to amyloid, but stain negative on Congo red (2).

The tumor has a high cellularity represented by imperceptibly reticulated to compact fascicles of spindle cells, which are intermixed with epithelial structures. The spindle cells have a mesenquimal appearance, with scanty to moderate slightly eosinophilic cytoplasm. The nuclei are elongated or oval, with little pleomorphism, pointed ends, fine chromatin, well defined nuclear membranes and inconspicuous nucleoli. These cells present with a relatively monomorphic aspect, and sometimes with plump features and evident epithelial differentiation $(1,6,9,10)$.

The cells with evident epithelial differentiation may be arranged in cords, narrow complex tubules, short pseudopapillae, trabecular islands or solid sheets. In many cases, there are cystic branched glands lined by ciliated pseudo-stratified epithelium with goblet cells. There may be squamous or mucinous epithelium with cuboidal to columnar nuclei and calcification foci (17-21).

Interstitial mucin pools and intercellular edema are seen frequently (17). Vascular invasion can be present $(6,17)$. Lymphocytes are rare or absent (19).

Mitotic figures are uncommon. A high mitotic index is rare and necrosis is unusual (19). Kirby and cols. (16) observed a high cellularity at the periphery of the tumor near the resection margin, and that the mitotic index increased from the center ( 1 to 2 mitosis per 10 high-power fields) to the periphery of the tumor (10 to 20 mitosis per 10 high-power fields) (16).

In general, the distant metastasis of SETTLE retains the same morphology of the original tumor (8).

By definition, SETTLE has an epithelial phenotype of both spindle and clearly epithelial components, as demonstrated by strong and diffuse immunostaining for cytokeratins (CK), mostly pan-CK.

Vimentin can be expressed in both components of SETTLE, with positivity varying from only $20 \%$ of the spindle cells to diffuse for both components $(2,18,21)$. The expression of EMA is also variable, but with focal predominance of the epithelial component $(8,2,18,20)$.

The evident epithelial component does not show, generally, positivity for muscular or neuroendocrine differentiation antibodies. Kirby and cols. (16) reported minimal positivity for smooth muscle actin and NSE in the evident epithelial component (16). Otherwise, Su and $\mathrm{Xu}$ observed diffuse immunostaining for smooth muscle actin in the spindle cell component $(6,21)$. We also found expression of smooth muscle actin, which was strong and diffuse in both components, suggesting a myoepithelial differentiation, as found in the other case reports.

The two components of SETTLE are always negative for thyroglobulin, calcitonin, chromogranin A, synaptophysin, CEA, desmin and S-100 protein $(2,6,8,16,18,21)$. Special care is required in cases with trapping of normal thyroid follicles, because when stained with thyroglobulin, the tumoral cells can stain positive due to overflow of the antibody (16).

$\mathrm{Xu}$ and Cheuk reported negativity for CD5 (which is expressed in high number of thymic carcinoma, including CASTLE) and for CD20 (which is expressed in high number of the spindle cells of spindle thymoma) $(21,8)$. Cheuk and cols. (8) still showed negativity for terminal deoxynucleotide transferase (TdT), which is expressed in immature $\mathrm{T}$ lymphocytes that accompany the thymomas (8).

Both immunohistochemical and ultrastructural features confirm the epithelial phenotype of SETTLE. The finding of tonofilaments and desmosomes in all cases studied, in both spindle and clear epithelial cells, demonstrates the epithelial differentiation of the spindle cells $(2,6)$. Additionally, Su and cols. (6) found the presence of intracytoplasmic thin filaments with fusiform dense bodies, which suggested, together with immunoreactivity for smooth muscle actin, a myoepithelial differentiation (6).

In the first and unique molecular genetic study of SETTLE in the literature, $\mathrm{Xu}$ and cols. (21) reported mutations of Ki-ras oncogene, which cast grave doubts on the presence of thymic differentiation. There have been no reports of ras gene mutations in thymic epithelial tumors so far. 
The differential diagnosis includes many epithelial and biphasic spindle cell tumors of the head and neck which needs a correlation with clinical, radiological, pathological and immunohistochemical findings (6).

Among the tumors derived from branchial or thymic remnants, "ectopic hamartomatous thymoma" is a benign tumor, compounded by an admixture of plump spindle cells, delicate fibroblast-like spindled cells, mature adipose tissue, and epithelial elements with squamous, glandular or indeterminate morphology. This tumor, which has recently been proposed to be called branchial anlage mixed tumor by Fetsch and cols., generally affects males (male-to-female ratio $>10: 1$ ), with a median age of 42.5 years, and can be found in the lower neck, sternoclavicular and presternal regions (22). In addition to the age of the patients (older adults) and the site of the tumor (never affecting the thyroid gland), the presence of mature adipose tissue (present in all cases), rules out this tumor. Ectopic cervical thymoma is a benign tumor, with a jigsaw puzzle appearance, comprised of plump spindle or epithelial cells, which often presents with lymphocytes and occurs in females, with a mean age of 42.7 years. The finding of lymphocytes admixed with the cells in most cases, besides the older age group, helps to differentiate from SETTLE. The third lesion that comprises this group is CASTLE. This tumor does not effectively make differential diagnosis with SETTLE, since this is clearly a malignant neoplasm, which resembles thymic carcinoma with lymphoepithelioma-like pattern and occurs in older patients (mean age of 48.5 years) $(6,19,20)$.

In general, thymomas, and mostly the spindle cell variant, present with the characteristic jigsaw puzzle-like lobulation, in addition to CD20 and TdT immunostaining, ultrastructurally interdigitating cell processes, and lack of glands, as found in SETTLE (8).

Teratomas of the thyroid gland are differentiated from SETTLE based on the finding of mature elements, originated from the 3 germ cell layers (6).

The spindle cell variant of medullar thyroid carcinoma (MTC) can occur in the same age group as SETTLE, although the finding of prominent fibrovascular septa, amyloid, occasional to frequent mitotic figures and lack of glands, suggests MTC. Furthermore, the immunostaining for calcitonin, chromogranin and CEA confirms the diagnosis of MTC (6).

The spindle cell variant of anaplastic thyroid carcinoma is easily differentiated based on the clinical data, which includes older patients (mean age between 60 and 65 years), and history of rapid tumor growth associated with hoarseness, dysphagia, and dyspnea. The pathologic features resemble a high-grade sarcoma, with prominent cellular pleomorphism, necrosis, high mitotic index, vascular invasion, prominent vascularity, giant cells, and wide extrathyroid extension. The immunohistochemistry may show positivity for cytokeratins and CEA, with invariably negative thyroglobulin $(6,16)$.

Synovial sarcoma (SS) is the most difficult differential diagnosis. Clinically, symptoms are often present and there is a rapid tumor growth. The spindle cells are usually monomorphic, hyperchromatic, but present a higher mitotic index. The glandular component is well differentiated, but does not display mucinous or goblet cells. The immunohistochemical study seems to be the best way to distinguish between SS and SETTLE. It reveals only patchy immunopositivity for cytokeratins, (which is strongest in the epithelial cells), strong positivity for vimentin and EMA staining (reliable marker of SS). In addition, there is usually strong and diffuse immunostaining for CD99 and BCL-2 protein. The ultrastructural lack of tonofilaments, as well as the specific translocation $\mathrm{t}(\mathrm{x} ; 18)(\mathrm{pl} 1.2 ; \mathrm{q} 11.2)$, involving the gene SS18 (SYT or SSXT) in chromosome 18, and the genes SSX1, SSX2 and SSX4 in chromosome X, support this distinguishing $(2,3,16,18,23)$.

In the literature, all cases (1,2,3,5-16,18,21,24-33) of SETTLE were treated with surgical resection of the tumor. Adjuvant chemo and radiotherapy were performed in some cases, although the role of the best scheme is not clear. Both chemo and radiotherapy administered after surgery led to complete metastatic disease remission in one case (29).

In conclusion, this case report showed the first report from Brazil and the possibility of a myofibroblastic differentiation. The SETTLE is among four tumors related to the thyroid, easily differentiated by clinicpathologic correlation. It is a low-grade malignant neoplasm, with epithelial differentiation confirmed by immunohistochemical and ultrastructural analysis. Despite all the descriptions in the literature, this tumor remains with uncertain histogenesis and lacking convincing proof of thymic differentiation or branchial pouch derivation. SETTLE can metastasize a long time after the surgical resection. Because of this, the patients need long-term follow-up, with particular attention to monitoring the lungs. Therefore, the early detection and surgical resection of the tumor constitute the primary 
treatment, despite the addition of radiotherapy and/or chemotherapy.

Acknowledgements: According to Ethics Committee's recommendations the authors had the patient's legal representative's consent and the patient's assent to report this case.

Disclosure: no potential conflict of interest relevant to this article was reported.

\section{REFERENCES}

1. Chan JKC, Rosai J.Tumors of the neck showing thymic or related branchial pouch differentiation: a unifying concept. Hum Pathol. 1991;22:349-67.

2. Saw D, Wu D, Chess $Q$, Shemen L. Spindle epithelial tumor with thymus-like element (SETTLE), a primary thyroid tumor. Int $\mathrm{J}$ Surg Pathol. 1997;4:169-74.

3. Bradford CR, Devaney KO, Lee JI. Spindle epithelial tumor with thymus-like differentiation: a case report and review of the literature. Otolaryngol Head Neck Surg. 1999;120:603-6.

4. Hadju SI, Hadju EO. Malignant teratoma of the neck. Arch Pathol Lab Med. 1967;83:567-70.

5. Weigensberg C, Daisley H, Asa SL, BedardY, Mullen JBM. Thyroid thymoma in childhood. Endocr Pathol. 1990;1:123-7.

6. Su L, Beals T, Bernacki EG, Giordano TJ. Spindle epithelial tumor with thymus-like differentiation: a case report with cytologic, histologic, immunohistologic, and ultrastructural findings. Mod Pathol. 1997;10:510-4.

7. Murao T, Nakanishi M, Toda K, Konishi H. Malignant teratoma of the thyroid gland in na adolescent female. Acta Pathol Jap. 1979;29:109-17.

8. Cheuk W, Jacobson AA, Chan JK. Spindle epithelial tumor with thymus-like differentiation (SETTLE): a distinctive malignant thyroid neoplasm with significant metastatic potential. Mod Pathol. 2000;13:1150-5.

9. Erickson ML,Tapia B, Moreno ER, McKee MA, Kowalski DP, ReyesMúgica M. Early metastasizing spindle epithelial tumor with thymus-like differentiation (SETTLE) of the thyroid. Pediatr Dev Pathol. 2005;8(5):599-606.

10. Kloboves-Prevodnik V, Jazbec J, Us-Krasovec M, Lamovec J. Thyroid spindle epithelial tumor with thymus-like differentiaion (SETTLE): is cytopathological diagnosis possible? Diagn Cytopathol. 2000;26:314-9.

11. Abrosimov AY, LiVolsi VA. Spindle epithelial tumor with thymuslike differentiation (SETTLE) neck lymph node metastasis: a case report. Endocr Pathol. 2005;16(2):139-43.

12. Levey M. An unusual thyroid tumor in a child. Laryngoscope. 1976; 86:1864-8.

13. Kingsley DPE, Elton A, Bennett MH. Malignant teratoma if the thyroid: case report and a review of the literarure. $\mathrm{Br} \mathrm{J}$ Cancer. 1968;22:7-11.

14. Williams ED. Presented at the World Health Organization meeting for the classification of thyroid tumors; Zurich, Switzerland; 1986.

15. Trabelsi A, Stita W, Zakhama A, Mokni M. An enlarged thyroid in a 20-year-old woman. Arch Pathol Lab Med. 2006;130:405-6.
16. Kirby PA, Ellison WA, Thomas PA. Spindle epithelial tumor with thymus-like differentiation (SETTLE) of the thyroid with prominent mitotic activity and focal necrosis. Am J Surg Pathol. 1999;23:712-6.

17. Rosai J, Carcangiu ML, DeLellis RA. Miscellaneous tumors. In: Tumors of the thyroid gland. Washington, D.C.: Armed Forces Institute of Pathology; 1990. p. 282-5.

18. Chetty R, Goetsch S, Nayler S, Cooper K. Spindle epithelial tumor with thymus-like element (SETTLE): the predominantly monophasic variant. Histopathology. 1998;33:71-4.

19. Fletcher CDM. Diagnostic histopathology of tumors. 2nd ed. London: Churchill Livingstone; 2002.

20. Rosai J. Rosai and Ackerman's Surgical Pathology. 9th ed. Philadelphia: Mosby; 2004.

21. Xu B, Hirokawa M, Yoshimoto K, Miki H, Takahashi M, Kuma S, et al. Spindle epithelial tumor with thymus-like differentiation of the thyroid: a case report with pathological and molecular genetics study. Hum Pathol. 2003;34(2):190-3.

22. Fetsch JF, Laskin WB, Michal M, Remotti F, Heffner D, Ellis G, et al. Ectopic hamartomatous thymoma: a clinicopathologic and immunohistochemical analysis of 21 cases with data supporting reclassification as a branchial anlage mixed tumor. Am J Surg Pathol. 2004;28:1360-70.

23. Fisher C, De Bruijn DRH, Van Kessel AG. Synovial sarcoma. In: Fletcher DM, Unni KK, Mertens F, editors. Tumors of soft tissue and bone. Lion: OMS; 2002.

24. Hofman P, Mainguene C, Michiels JF, Pages A, Thyss A. Thyroid spindle epithelial tumor with thymus-like differentiation (the "SETTLE" tumor): an immunohistochemical and electron microscopic study. Euro Arch Otorhinolaryngol. 1995;252:316-20.

25. Iwasa K, Imai MA, Noguchi M, Tanaka S, Sasaki T, Katsuda S, et al. Spindle epithelial tumor with thymus-like differentiation (SETTLE) of the thyroid. Head Neck. 2002;24:888-93.

26. Satoh S, Toda S, Narikawa K, Watanabe K, KuratomiY, Sugihara H, et al. Spindleepithelial tumor with thymus-like differentiation (SETTLE): patient. Pathol Int. 2006;56(9):563-7.

27. Tong GX, Hamele-Bena D, Wei XJ, Toole K. Fine-needle aspiration biopsy of monophasic variant of spindle epithelial thymus-like differentiaion of the thyroid: report of one case and review of the literature. Diagn Cytophathol. 2007;35(2):113-9.

28. Haberal AN, Aydin H, Turan E, Demirhan B. Unusual spindle cell tumor of thyroid (SETTLE). Thyroid. 2008;18(1):85-7.

29. Raffel A, Cupisti K, Rees M, Janig U, Bernbeck B, Jazbec J, et al. Spindle epithelial tumor with thymus-like differentiation (SETTLE) of the thyroid gland with widespread metastasis in a 13-year-old girl. Clin Oncol. 2003;15:490-5.

30. Murao T, Nakanishi M, Toda K, Konishi H. Malignant teratoma of the thyroid gland in na adolescent female. Acta Pathol Jap. 1979;29:109-17.

31. Lee FY, Wen MC, Jan YJ, Wang J. The predominant monophasic variant of spindle epithelial tumour with thymus-like differentiation (SETTLE) of neck soft tissue with late pulmonary metastasis. Pathology. 2010;42(2):188-90.

32. Amji S, Trimeche S, Nouira M, Sfar R, Trabelsi A, Essabbah H. Spindle epithelial tumor with thymus-like differentiation of the thyroid. Clin Nucl Med. 2008;33(12):887-8.

33. Grushka JR, Ryckman J, Mueller C, Roessingh Ade B, Walton JM, St Vil D, et al. Spindle epithelial tumor with thymus-like elements of the thyroid: a multi-institutional case series and review of the literature. J Pediatr Surg. 2009;44(5):944-8. 